\title{
Humoral and Cellular Immunity to Candida albicans in Patients with Bronchial Asthma
}

\author{
Yoshiro Tanizaki, Hikaru Kitani, Morihiro Okazaki, Takashi Mifune and Fumihiro Mitsunobu
}

\begin{abstract}
Delayed cutaneous reactivity to Candida albicans (C. albicans) and PPD (purified protein derivative) was examined in 52 patients with bronchial asthma in relation to the production of specific $\mathrm{IgG}_{4}$ antibodies against the antigen. 1. The frequency of a positive, immediate skin reaction to $C$. albicans was similar among the five age groups, ranging from $60.0 \%$ to $66.7 \%$. 2. The incidence of a positive delayed skin reaction to $C$. albicans was lower in patients between the ages of 10 and 30 and tended to decrease with aging in the patients over the age of 51. 3. A delayed skin reaction to PPD was positive in patients between 31 and 50 with a higher incidence; this incidence decreased in patients over age 51. 4. The level of $C$. albicans-specific $\operatorname{IgG}_{4}$ antibodies was significantly higher $(26.7 \mathrm{u} / \mathrm{ml})$ in patients with a negative delayed skin reaction to the antigen than in those with a positive reaction $(5.9 \mathrm{u} / \mathrm{ml})(\mathbf{p}<0.001)$. There was no correlation between delayed skin reaction to PPD and production of specific $\operatorname{IgG}_{4}$ antibodies. (Internal Medicine 31: 766-769, 1992)
\end{abstract}

Key words: specific $\operatorname{IgG}_{4}$, delayed cutaneous hypersensitivity, PPD, atopics, aging

\section{Introduction}

Candida albicans (C. albicans) is a common antigen found in patients with bronchial asthma. The antigen causes IgE-mediated allergic reactions in asthmatics $(1-3)$. It has been shown that $\mathrm{IgE}$ and $\mathrm{IgG}_{4}$ antibodies participate in immediate immune response. The response mediated by $\operatorname{IgE}$ plays an important role in the onset mechanism of bronchial asthma $(4,5)$. The role of $\operatorname{IgG}_{4}$ antibodies, whether anaphylactic or protective, is however still controversial $(6-10)$. Patients who have IgEmediated immune responses which cause asthma attacks are evaluated as atopic $(11,12)$. It has been suggested that delayed immune responses are depressed in these patients (13). An increased production of specific IgG antibodies to $C$. albicans (14) and a diminished delayed skin reaction have been observed in some atopics (13, 15). A depressed delayed immune response leads to saprophytic $C$. albicans growth, which accelerates the production of specific IgG antibodies $(16,17)$; this is due to the fact that in the cell-mediated immune system plays a major role in the defense against $C$. albicans (18).

In the present study, the delayed cutaneous hypersensitivity to $C$. albicans and PPD (purified protein derivative) was examined in patients with bronchial asthma to evaluate the relationships between IgE-mediated allergic reactions to depressed cell-mediated immune response and those to the increased production of specific $\mathrm{IgG}_{4}$ antibodies. $\mathrm{IgG}_{4}$ antibodies, which may participate in immediate allergic response $(6-10)$, were selected to examine the changes in the $\operatorname{IgG}$ response to $C$. albicans.

\section{Subjects and Methods}

Fifty-two patients (38 females and 14 males) with bronchial asthma, with a mean age of 48.6 years (range, 11 to 77 years) were divided into five groups according to age: 1) 10-30 years, 2) $31-50$ years, 3) 51-60 years, 4) 61-70, and 5) 71 years and over.

An intradermal skin test was performed with $0.02 \mathrm{ml}$ of commercial Candida allergen extract (Torii Co, Japan) and by intradermal injection of $0.1 \mathrm{ml}$ PPD (Japan BCG $\mathrm{Co}$ ). The diameters of flare and wheal at 20 minutes, and flare and induration at 48 hours were measured after the test. A flare diameter of larger than $20 \mathrm{~mm}$ or a wheal diameter of larger than $9 \mathrm{~mm}$ was regarded as positive in the immediate skin reaction. A flare or induration diameter of larger than $10 \mathrm{~mm}$ was regarded as positive in the delayed skin reaction.

C. albicans-specific $\operatorname{IgG}_{4}$ antibodies were measured by an indirect enzyme-linked immunosorbent assay (ELISA) (19) modified from that described by Engvall and Perlmann (20). Polystyrene microtiter plates were coated with $100 \mu \mathrm{l}$ of $C$. albicans extract (Torii Co)

From the Division of Medicine, Misasa Medical Branch, Okayama University Medical School, Tottori

Received for publication October 17, 1991; Accepted for publication March 13, 1992

Reprints requests should be addressed to Dr. Yoshiro Tanizaki, the Division of Medicine, Misasa Medical Branch, Okayama University Medical School, 827 Yamada, Misasa, Tottori 682-01, Japan 
at a 1:20,000 dilution in phosphate-buffered saline (PBS) at $4^{\circ} \mathrm{C}$ overnight, and then washed three times with PBSTween 20 . After washing, $200 \mu \mathrm{l}$ of $1 \%$ BSA-PBS was added to the wells, incubated for 1 hour at $37^{\circ} \mathrm{C}$, then discarded. Reference serum or serum samples at a 1:1,000 dilution in BSA-PBS were added and incubated at $37^{\circ} \mathrm{C}$ for 2 hours. Monoclonal anti-human $\mathrm{IgG}_{4}$ (Yamasa Shoyu Co.) was added to the wells at a 1:1,000 dilution in BSAPBS and incubated at $4{ }^{\circ} \mathrm{C}$ overnight. After washing, $100 \mu \mathrm{l}$ of peroxidase-conjugated anti-mouse IgG (Cappel Lab.) was added to the wells at 1:10,000 dilution in BSA-PBS for 1 hour at $37^{\circ} \mathrm{C}$. After another washing, the substrate, O-phenylenediamine, was added to the wells and incubated for 1 hour at room temperature. Color development was stopped by the addition of $100 \mu \mathrm{l}$ of $4 \mathrm{~N} \mathrm{H}_{2} \mathrm{SO}_{4}$, and the OD was determined at $500 \mathrm{~nm}$ (19). Specific $\mathrm{IgG}_{4}$ levels were expressed as arbitrary units per milliliter against a positive serum pool.

Specific IgE antibodies against house dust and $C$. albicans were examined by a radioallergosorbent test (RAST). The results were expressed by a score from $0+$ to $4+$ and a score of $2+$ or more was evaluated as positive, meaning sensitization by the allergen. The level of total serum IgE was measured by a radioimmunosorbent test (RIST).

\section{Results}

\section{Characteristics of the patients}

The mean level of serum total $\mathrm{IgE}$ was the highest in the patients between the ages of 10 and 30 , and the level was significantly higher than that in those between the ages of 31 and $50(\mathrm{p}<0.001)$. The frequency of a positive RAST score to house dust and/or C. albicans was the highest in the patients between the ages of 10 and 30 , in which $11(84.6 \%)$ of the 13 patients showed a positive RAST. The frequency of a positive RAST score was the lowest $(11.1 \%)$ in patients over the age of 71 . The patients with steroid-dependent intractable asthma (SDIA) was most frequently observed in those between 51 and 60. The frequency of SDIA was the lowest in patients aged between 10 and 30 . The results indicate that many of the patients aged between 10 and 30 were

Table 1. Characteristis of Patients Classified by Age

\begin{tabular}{lcccc}
\hline $\begin{array}{l}\text { Age } \\
\text { years }\end{array}$ & $\begin{array}{c}\text { No. of } \\
\text { cases }\end{array}$ & $\begin{array}{c}\text { Serum IgE } \\
(\mathrm{IU} / \mathrm{ml})\end{array}$ & $\begin{array}{c}\text { RAST }+ \text { to } \\
\text { HD or Ca }\end{array}$ & $\begin{array}{c}\text { No. of cases } \\
\text { with SDIA }\end{array}$ \\
\hline $10-30$ & 13 & $849 \pm 620^{* \mathrm{a}}$ & $11(84.6 \%)$ & $1(7.7 \%)$ \\
$31-50$ & 11 & $228 \pm 234^{\text {a }}$ & $3(27.3 \%)$ & $3(27.3 \%)$ \\
$51-60$ & 9 & $469 \pm 441$ & $3(33.3 \%)$ & $6(66.7 \%)$ \\
$61-70$ & 10 & $442 \pm 497$ & $3(30.0 \%)$ & $4(40.0 \%)$ \\
$70+$ & 9 & $634 \pm 852$ & $1(11.1 \%)$ & $2(22.2 \%)$ \\
\hline
\end{tabular}

* Mean \pm sd, HD: house dust, Ca: Candida albicans, SDIA: steroiddependent intractable asthma. ${ }^{a}: p<0.001$. Number in parentheses represents the percentage of all subjects in each age group atopic asthmatics, while many of those between the ages of 51 and 60 had SDIA (Table 1).

\section{Delayed skin reaction and patient age}

The incidence of patients with a positive immediate skin response to C. albicans was from 60.0 to $66.7 \%$. Among the five age groups, no differences were found. A delayed skin reaction to $C$. albicans was positive in 23 cases $(44.2 \%)$ and that to PPD was positive in 21 $(40.4 \%)$ of the 52 subjects. Compared with the other groups, the frequency of a positive delayed skin reaction to C. albicans was high in patients aged between 31 and $50(63.6 \%)$ and slightly high in those between 51 and 60 $(55.6 \%)$. The lowest frequency $(22.2 \%)$ was observed in patients aged over 71 . A delayed skin reaction to PPD was positive in patients aged between 31 and 50 with the highest frequency. The incidence of patients positive to PPD was lower in those between 10 and 30 years and showed a decreasing tendency in those over 51 (Fig. 1).

\section{Serum levels of C. albicans-specific $1 g G_{4}$ antibodies in each age group}

C. albicans-specific $\mathrm{IgG}_{4}$ antibody levels were the highest in patients over age 71 and the lowest in those between 31 and 50. A significant difference was present between the two groups $(p<0.05)$. The patients aged between 10 and 30 and between 61 and 70 had considerably high concentrations of $C$. albicans-specific $\mathrm{IgG}_{4}$ antibodies. The level of $C$. albicans-specific $\mathrm{IgG}_{4}$ in patients between 51 and 60 , who showed a slightly suppressed delayed skin reaction to $C$. albicans, was similar to the level in those between 61 and 70 (Table 2).

\section{Delayed skin reactivity to $C$. albicans and serum levels of specific $\mathrm{Ig}_{4}$ antibodies}

The mean level of $C$. albicans-specific $\mathrm{IgG}_{4}$ antibodies in the patients with a negative reaction to the

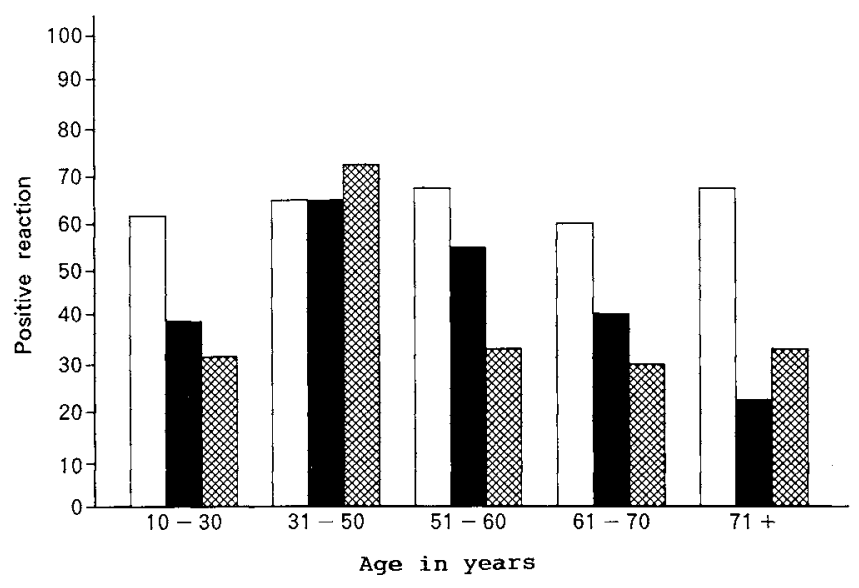

Fig. 1. Immediate (ㅁ) and delayed cutaneous reaction to $C$. albicans $(\boldsymbol{-})$, and delayed reaction to PPD (purified protein derivative) ( in patients with bronchial asthma. 


\section{Tanizaki et al}

Table 2. Serum Levels of C. albicans-specific $\operatorname{IgG}_{4}$ of Asthmatics of Various Age Groups

\begin{tabular}{lcc}
\hline $\begin{array}{l}\text { Age } \\
\text { years }\end{array}$ & $\begin{array}{c}\text { No. of } \\
\text { cases }\end{array}$ & $\begin{array}{c}\text { Specific } \text { IgG }_{4} \text { antibodies } \\
(\mathrm{u} / \mathrm{ml}) \text { (mean } \pm \mathrm{sd})\end{array}$ \\
\hline $10-30$ & 13 & $19.6 \pm 22.4$ \\
$31-50$ & 11 & $7.1 \pm 7.4^{\mathrm{a}}$ \\
$51-60$ & 9 & $14.5 \pm 13.9$ \\
$61-70$ & 10 & $15.7 \pm 10.8$ \\
$71+$ & 9 & $25.0 \pm 10.8^{\mathrm{a}}$ \\
\hline
\end{tabular}

a: $\mathrm{p}<0.05$

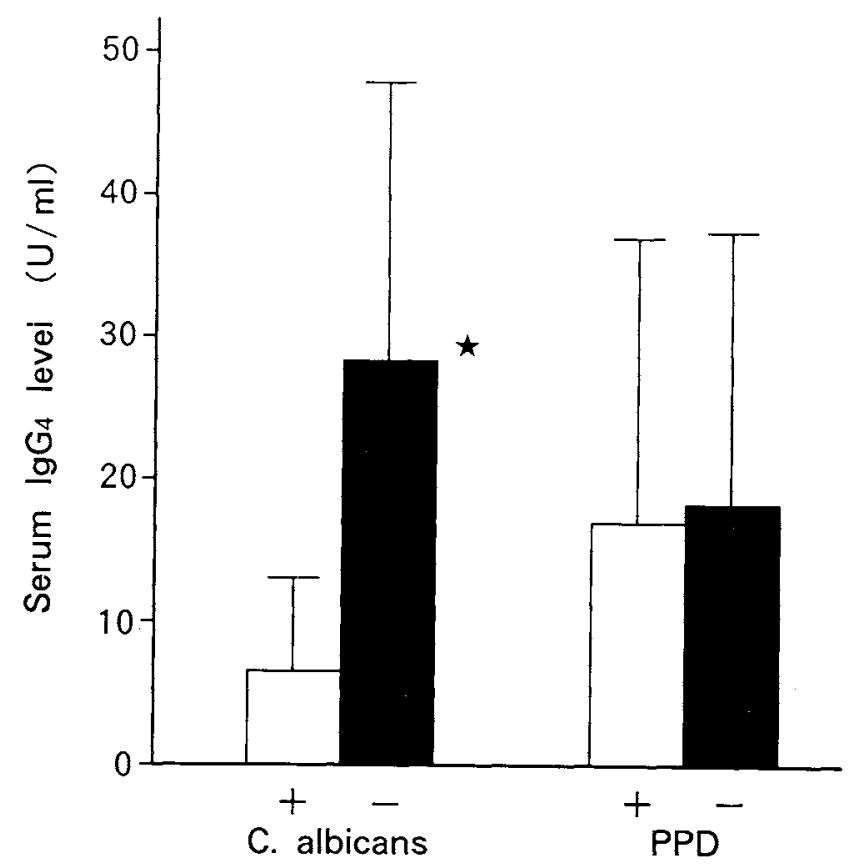

Fig. 2. Serum levels of $C$. albicans-specific $\operatorname{IgG}_{4}$ antibodies in patients with bronchial asthma in relation to a delayed cutaneous reaction to $C$. albicans and PPD (purified protein derivative). *Significant difference from the level of negative patients at $\mathrm{p}<0.001$.

antigen was $25.8 \pm 21.4 \mathrm{u} / \mathrm{ml}$ and the level in those that were positive, was $6.0 \pm 6.3 \mathrm{u} / \mathrm{ml}$. A significant difference in the level of specific $\operatorname{IgG}_{4}$ antibodies against $C$. albicans was found between the two groups $(p<0.001)$. On the contrary, the mean level of the patients with a positive delayed skin reaction to PPD was $16.5 \pm 19.8 \mathrm{u} / \mathrm{ml}$ and the level in those with a negative reaction was $17.5 \pm 19.0 \mathrm{u} / \mathrm{ml}$. No significant difference was observed between the patients with positive and negative reactions to PPD (Fig. 2).

\section{Discussion}

Various allergic and immunological reactions are common in patients with bronchial asthma. The main immunoglobulin produced by exposure to an allergen is $\operatorname{IgE}$ antibody in atopic asthmatics. $\operatorname{IgG}$ antibodies and the subclasses, $\operatorname{IgG}_{1}$ and $\operatorname{IgG}_{4}$ are also produced by stimulation with an allergen. In addition to these humoral immunological reactions, cell-mediated immune reaction to an allergen is sometimes observed in asthmatics. C. albicans has been considered the most common allergen in bronchial asthma (1); this allergen induces production of $\operatorname{IgE}, \operatorname{IgA}$ and $\operatorname{IgG}$ antibodies (17), and further elicits cell-mediated immune response (13).

Asthma induced by $C$. albicans may be complex and different from that elicited by the house dust mite (1-3). Upon bronchial challenge with $C$. albicans, an immediate asthmatic response (IAR), often a late asthmatic response (LAR) and sometimes a delayed response can be observed. C. albicans-induced asthma has been often observed in patients over the age of $40(3,21,22)$. The level of specific IgG to $C$. albicans increases with aging (22). Regarding humoral immune response, an increased level of specific $\mathrm{IgG}$ antibodies including $\mathrm{IgG}_{1}$ and $\mathrm{IgG}_{4}$ has been observed in some atopic subjects $(16,17)$. Two mechanisms have been proposed for the increased production of IgG antibodies associated with $\mathrm{IgE}$-mediated immune response: 1) increased production of IgG and IgE antibodies is due to a generally increased permeability of mucosal membranes in atopic subjects with inhalant allergens $(23,24)$, in whom similar synthesis system between $\mathrm{IgE}$ and $\mathrm{IgG}_{4}$ has been shown by several investigators $(25,26)$, and 2$)$ increased IgG levels might result from depressed cellmediated immunity in the $C$. albicans-induced reaction in atopic subjects $(16,17)$.

In this study, cell-mediated immune response to C. albicans and PPD was observed in patients with bronchial asthma in relation to the production of specific $\operatorname{IgG}_{4}$ antibodies. In C. albicans-induced immune response, cell-mediated immunity acts to defend against $C$. albicans invasion (18). A defect in cell-mediated immunity primarily causes saprophytic $C$. albicans growth. Therefore, it has been proposed that the increased production of specific IgG antibodies against $C$. albicans is due to a depressed cell-mediated immune response $(16,17)$.

This study showed that a depressed delayed cutaneous reaction to $C$. albicans often occured in younger (10-30 years) and older patients (61-70 and $71+$ years), whereas increased $C$. albicans specific- $\operatorname{Ig} G_{4}$ levels was found in the younger patients and those over 71 . These results demonstrate that depressed cell-mediated immunity to C. albicans, but not to PPD, is associated with the rise of specific $\operatorname{IgG}_{4}$ antibodies against the antigen. It has been reported that a depressed cell-mediated immune response often occurs in some atopic subjects $(13,15)$. In the present study, delayed skin reactivity to $C$. albicans was suppressed in patients aged between 10 and 30 , the majority $(84.6 \%)$ of whom were atopics showing a positive RAST. We speculate that the depressed cellmediated immune response in the patients between 10 and 30 is associated with the state of being atopic. Among the patients over 61 , an increase in specific $\operatorname{IgG}_{4}$ 


\section{Cellular Immunity in Asthmatics}

levels relating to diminished cell-mediated immunity, was also found, suggesting that the cell-mediated immune system might be depressed with aging.

Among the patients between 51 and 60, the incidence of a negative delayed skin reaction to $C$. albicans was slightly increased and higher specific $\mathrm{IgG}_{4}$ levels were observed compared with those between ages 31 and 50, although no significant difference was present in the levels of $\mathrm{IgG}_{4}$ between the two groups. The depressed delayed skin reaction may have been caused by long-term corticosteroid regimens, since this group included many patients $(66.7 \%)$ with steroid-dependent intractable asthma (SDIA). An increase in specific $\mathrm{IgG}_{4}$ antibodies against $C$. albicans has been observed in patients with SDIA (27).

These findings indicate that suppression of cellmediated immune response can be observed in atopic and elderly patients, as well as in those receiving long-term corticosteroid therapy. Also under these conditions, the production of specific IgG antibodies is predominantly increased, leading to a complex onset mechanism of bronchial asthma. It can be speculated from our data that a depressed cell-mediated immunity and an elevation of IgG antibodies to C. albicans is observable in elderly healthy subjects. Further studies are necessary to clarify the correlation of increased $C$. albicans specific- $\operatorname{IgG}_{4}$ antibodies and the pathogenesis of bronchial asthma.

\section{References}

1) Tanizaki $Y$, Komagoe H, Sudo $M$, et al. Candida-induced histamine release from basophils: Relationship to house dust- and anti-IgE-induced secretion. Acta Med Okayama 39: 191, 1985.

2) Tanizaki $Y$, Komagoe $H$, Sudo $M$, et al. Basophil histamine release by Candida albicans. Relationship to specific IgE and IgG antibodies. Jpn J Allergol 34: 422, 1985.

3) Tanizaki $Y$, Komagoe H, Sudo M, Morinaga H, Kitani H, Kimura I. Comparison of basophil histamine release induced by the crosslinking of IgE receptors. Acta Med Okayama 39: 441, 1985.

4) Ishizaka T, Ishizaka K, Conrad DH, Froese A. A new concept of mechanisms of IgE-mediated histamine release. J Allergy Clin Immunol 64: 320, 1978.

5) Ishizaka T, Hirata F, Ishizaka K, Axelrod J. Stimulation of phospholipid methylation, $\mathrm{Ca}^{2+}$ influx and histasmine release by bridging of $\operatorname{IgE}$ receptors on rat mast cells. Proc Natl Acad Sci USA 77: 1903, 1980.

6) Aalberse RC, Gaag R van der, Leewen J van. Serologic aspects of $\mathrm{IgG}_{4}$ antibodies. 1. Prolonged immunization results in an $\mathrm{IgG}_{4}$-restricted response. J Immunol 130: 722, 1983.

7) Giessen $M$ van der, Homan WL, Kernebeck G van, Aalberse RD, Dieges PH. Subclass typing of IgG antibodies formed by grass pollen-allergic patients during immunotherapy. Int Arch Allergy Appl Immunol 50: 625, 1976.

8) Nakagawa $T$, Miyamoto $T$. The role of $\mathrm{IgG}_{4}$ as blocking antibodies in asthmatics and in bee keepers. Int Arch Allergy Appl Immunol 77: 204, 1985.

9) Djurup R. The subclass nature and clinical significance of the $\mathrm{IgG}$ antibody response in patients undergoing allergen specific immunotherpy. Allergy 40: 469, 1986.

10) Chernokhvostova EV, Kotova TS, Ferman GP, Atovmian OI. $\mathrm{IgG}_{4}$ antibodies in hay fever patients. Difference in $\mathrm{IgG}_{4}$ response to tree pollen and grass pollen allergens. Int Arch Allergy Appl Immunol 92: 217, 1990.

11) Tanizaki $Y$, Komagoe H, Morinaga H, Kitani H, Goda $Y$, Kimura I. Allergen- and anti-IgE-induced histamine release from whole blood. Int Arch Allergy Appl Immunol 73: 141, 1984.

12) Tanizaki $Y$, Komagoe $H$, Sudo M, et al. Reactivity of sensitized human basophils, as expressed by histamine release. Jpn J Allergol 33: 463, 1984.

13) McGeady SJ, Buckley RH. Depression of cell-mediated immunity in atopic eczema. J Allergy Clin Immunol 56: 393, 1975.

14) Pepys J, Faux JA, Longbottom JL, McCarthy DS, Hargreave FE. Candida albicans precipitins in respiratory disease in man. J Allergy 41: 305, 1968.

15) Elliot ST, Hanifin JM. Delayed cutaneous hypersensitivity and lymphocyte transformation. Arch Dermatol 115: 36, 1979.

16) Savolainen J, Viander M, Koivikko A. IgE, $\operatorname{IgA}$ and $\operatorname{IgG}$ antibody responses to carbohydrate and protein antigens of Candida albicans in asthmatic children. Allergy 45: 54, 1990.

17) Savolainen J, Koivikko A, Kalimo K, Nieminen E, Viander $M$. $\mathrm{IgE}, \operatorname{IgA}$ and $\mathrm{IgG}$ antibodies and delayed skin response towards Candida albicans antigens in atopics with and without saprophytic growth. Clin Exp Allergy 20: 549, 1990.

18) Rogers TI, Balish E. Immunity to Candida albicans. Microbiol Rev 44: 660, 1980.

19) Nakagawa $T$, Takaishi $T$, Sakamoto $Y$, Ito $K$, Miyamoto $T$, Skvaril F. $\operatorname{IgG}_{4}$ antibodies in patients with house dust mite sensitive bronchial asthma; Relationship with antigen specific immunotherapy. Int Arch Allergy Appl Immunol 71: 122, 1983.

20) Engvall E, Perlmann P. Enzyme-linked immunosorbent assay, ELISA. III. Quantitation of specific antibodies by enzyme-labeled anti-immunoglobulin in antigen-coated tubes. J Immunol 109: $129,1972$.

21) Tsukioka K. Studies on the mechanism developing bronchial asthma due to Candida albicans. 1. A comparative study of clinical features among Candida-induced astham and house dust-induced asthma. Jpn J Allergol 30: 919, 1981 (in Japanese).

22) Tanizaki $\mathrm{Y}$, Komagoe $\mathrm{H}$, Sudo $\mathrm{M}$, et al. Characteristics of Candida albicans in patients with bronchial asthma. Statistical analysis. Jpn J Thorac Dis 24: 150, 1986 (in Japanese).

23) Calkhoven PG, Aalbers M, Koshte VL, et al. Relationship between $\mathrm{IgG}_{1}$ and $\mathrm{IgG}_{4}$ antibodies to foods and the development of $\mathrm{IgE}$ antibodies to inhalant allergens. I. Establishment of a scoring system for the overall food responsiveness and its application to 213 unselected children. Clin Exp Allergy 21: 91, 1991.

24) Calkhoven PG, Aalbers $M$, ct al. Relationship between $\operatorname{IgG}_{1}$ and $\mathrm{IgG}_{4}$ antibodies to foods and the development of $\mathrm{IgE}$ antibodies to inhalant allergens. II. Increased levels of IgG antibodies to foods in children who subsequently develop $\operatorname{IgE}$ antibodies to inhalant allergens. Clin Exp Allergy 21: 99, 1991.

25) Nüsslein HG, Spiegelberg HL. The role of lymphokines in $\operatorname{IgE}$ and IgG subclass formation. in: progress in Allergy and Clinical Immunology, Pichler WJ, Stadler BM, Dahinden CA, Pecoud AR, Frei P, Schneider CT, de Weck AL, Eds. Hegrefe \& Huber, Toronto, 1989, p. 149.

26) Nüsslein $\mathrm{HG}$, Spiegelberg HL. Interleukin-4 induces both $\mathrm{IgG}_{4}$ and IgE secretion by peripheral blood B cells. J Clin Lab Anal 4: 414, 1990.

27) Tanizaki $Y$, Kitani $H$, Okazaki $M$, et al. Candida specific $\operatorname{IgG}_{4}$ antibodies and bronchial asthma. Papers of the Institute for environmental Medicine, Okayama University Medical School. 62: 1, 1991. 